\title{
Designing and Implementing Sustainability: An Integrative Framework for Implementing the Sustainable Development Goals
}

Jan Beyne ${ }^{1}, \mathrm{PhD}$

\begin{abstract}
Covering various sustainable development challenges, such as education, health, climate change and inequality, the Sustainable Development Goals or SDGs can help to strengthen current business sustainability strategies with global aspirations. A review of sustainability literature and existing SDG frameworks provides the background to develop an integrative framework of SDG implementation in business strategies and operations as a pathway for sustainable transformation.

This article offers a preliminary review of the efforts being made by businesses to address the SDGs. The resulting integrative framework highlights four SDG orientation levels that span seven steps of the SDG integration process, leading to sustainable transformation.
\end{abstract}

Keywords: SDGs; sustainable transformation; business strategy; implementation

\section{Introduction}

In 2000, with the adoption of the Millennium Development Goals (MDGs), companies became an important partner in creating social development. Meanwhile, it became clear that business cannot operate isolated from the problems that impact society as a whole (UNDP, 2015). There is an evolving interest in sustainable development by the private sector, evidenced by for example companies that have signed the UN Global Compact (UNGC, 2010). However, embedding sustainability agenda's and principles such as the MDGs or Global Compact - into business' strategies presents some serious challenges (Langer \& Schön, 2003).

With the adoption of Agenda 2030 in 2015, the Sustainable Development Goals (SDGs) define universal aspirations for 2030. Although fundamentally governments will need to tackle SDG implementation at a national level, business has a key role to play regarding innovation, finance, economic growth and employment (WBCSD, 2016). Furthermore, companies will need to pursue sustainability as a transformational agenda, i.e., firms will need to use their influence to support positive changes that ensure the achievement of sustainability targets for a sustainable society (Visser, 2017).

Although the corporate perspectives towards the SDGs have been approached in several discussion papers and practical reports (Agarwal et al., 2017; PwC, 2018), there is a need to better understand how companies integrate the Global Goals to pursue sustainable transformation. Many companies are still struggling how to integrate sustainability practices, as well as align their operations with the big sustainable development challenges reflected by the SDGs. 
At the same time, practitioners and academics call for a framework to implement the SDGs. In a Special Issue on the contribution of multinational enterprises to the Sustainable Development Goals, Witte \& Dilyard (2017) call for research on how companies are dealing with the SDGs in their organization, as there is no clear consensus in literature yet. Rosati \& Faria (2019) even specifically call for qualitative research to uncover drivers for companies to integrate SDGs in their communication and their reporting. Therefore, it is relevant that this article combines both practical and academic knowledge to develop an integrative framework for implementing the SDGs as a pathway for sustainable transformation and tackle the question: How effective are the SDGs in advancing sustainable transformation?

This article is organized as follows: First, we review sustainability literature, in particular existing SDG frameworks. Second, we outline the methodology. Next, we present the findings, including an integrative framework of SDG implementation as a pathway to sustainable transformation. Finally, we discuss the study's contributions, along with possible avenues for further research.

\section{Literature review}

In literature, different approaches to define, theorize, and measure corporate sustainability (CS) and corporate social responsibility (CSR) have been used (Wartick \& Cochran, 1985). Caroll (1999) started to trace the evolution of the CSR construct in the 1950s where it was referred to more as social responsibility (SR). Bowen (1953) quoted at that time that businessmen were responsible for the consequences of their actions. In the 1980s, alternative concepts such as corporate social performance (CSP), stakeholder theory and business ethics theory began to mature (Caroll, 1999), with ambitions to embrace the corporate sustainability objectives expressed in the Brundtland Report (Brundtland Commission, 1987). Dyllick \& Hockerts (2002) mirror their approach with the Brundtland definition and define CS as '... meeting the needs of a firm's direct and indirect stakeholders, such as shareholders, employees, clients, pressure groups, communities without compromising its ability to meet the needs of future stakeholders as well.

As two streams of responsibility and sustainability got moving (Visser, 2015), John Elkington (1994) coined the term 'triple bottom line' as an attempt to create a new model with three value grounds: social, environmental and economic aspects of value creation. Elkington (2004) argues that business will drive the processes of cultural revolution. Yet, this revolution is triggered by external challenges such as scarcity of food and water, material waste, as well as energy and transportation, where it is important for companies to be flexible and open to change (Senge, Smith, Kurschwitz, Laur, Schley, 2008). In line with these academic insights, Lozano (2012) defines CS as follows: 'Corporate activities that proactively seek to contribute to sustainability equilibria, including the economic, environmental, and social dimensions of today, as well as their inter-relations within and throughout the time dimension while addressing the company's system and its stakeholders'. This approach underscores a systems approach, which presents the same three themes as the Brundtland report, but confers different sizes and weightings to them (Giddings, 2002). 
The two definitions present the comparison between 'weak sustainability' (Brundtland definition) and 'strong sustainability' (the definition of Lozano). The first definition by the Brundtland Commission (1987) assigns the same weight to the triple bottom line; economy, environment, and society. This reductionist perspective places an emphasis on the constituent parts of a system (Morandín-Ahuerma, Contreras-Hernández, Ariel Ayala-Ortiz, \& Pérez-Maqueo, 2019). While reductionism breaks an entity down, holism tries to understand something in reference to the whole system and looks at the feasibility of incorporating different parts in one entire framework (Gasparatos, ElHaram, Horner, 2008). The definition of Lozano (2012) has an eco-centric perspective and is based on the idea that companies must be addressed holistically and systemically. In recent years, this holistic perspective has gained further ground and there is increasing recognition that companies' value creation include transformational value (Lozano, 2012).

Authors such as Epstein, Buhovac, and Yuthas (2015) showed that the tensions between CSR and Corporate Financial Performance (CFP) are a source of creative ideas for companies (Epstein, Buhovac, and Yuthas, 2015). Others argue that CSR spurs learning and innovation cycles (Vilanova, Lozano \& Arenas, 2009). And other academics claim that business models undergo constant change, in which sustainability plays a central role (Rautera, Jonker \& Baumgartner, 2017). All these new conceptions build on previous CSR and CS concepts, but call for greater integration which might lead to value creation (Visser, 2015).

Visser wants to go a step further beyond CSR by working out the 'how to' of integration (Visser, 2015). With the concept of Integrated Value Creation (IVC), Visser takes inspiration from many ideas already in circulation and analysed some important social, ethical and environmental guidelines and standards (Visser, 2015). IVC aims to be a tool for sustainable transformation with a 7-step process, in which stakeholder and risk assessment are crucial (Visser, 2015).

Pursuing 'strong sustainability' which leads to sustainable transformation could be considered as a new way of organizing the strategy and operations of a business (Dawson, 2003), in which the aim is to align a company to integrate its response to stakeholder expectations while considering global sustainability challenges. If business wants to tackle global sustainability challenges, CS strategies should evolve and result in structural transformations (Van De Ven \& Pool, 1995; Visser, 2015). Finally, in order to achieve this, we need to equip businesses with the right knowledge to address sustainability issues (Lozano, 2011).

The SDGs are recognized as an important framework for sustainable transformation by embedding sustainability into business operations and for improving stakeholder engagement (Mori, Fien \& Horne, 2019). In the past few years, the CS discourse is increasingly dominated by the SDGs as a new reference framework to sustainable development (Schönherr, Findler \& Martinuzzi, 2017). Schönherr, Findler \& Martinuzzi propose a research agenda to develop new management instruments to capture corporate impacts on sustainable development, as they recognize the private sector as both a leader and recipient in achieving the SDGs. 
Research shows several ways how the SDGs might be used in business strategies. However, the range of tools that help implementing and measuring progress on the SDGs is very broad and sometimes unclear for business (Van Tulder, 2018). In the UN resolution on the 2030 Agenda (UN, 2015), the SDGs were specifically positioned as a universal, indivisible and interlinked set of goals. In this context, we observe a lot of attention on the new term 'SDG rainbow washing', similar to the term 'green washing' (Laufer, 2003) meaning that companies only address the SDGs without actual integrating and contributing to all goals, because it is good for their reputation to be associated with the UN and the colourful SDG framework.

Overall, it seems that there is no clear consensus on how companies should implement the SDGs into their strategy and operations to pursue sustainable transformation (Van Tulder, 2018). Therefore, we compared well-known frameworks on SDG implementation: the SDG Compass, IR Value Creation Process, and the SDG Sector Roadmap, in order to integrate different perspectives into a single framework. Afterwards, we test and refine the preliminary model by analyzing the performance of sustainability business leaders and investigating the effectiveness of their SDG implementation process in advancing sustainable transformation.

\section{Methodology}

Because research on the topic of SDG implementation approaches is still in its infancy (Witte \& Dilyard, 2017), this study took an exploratory method (Saunders, Lewis, Bristow \& Thornhill, 2019). For this article, we refer to the systemic methodology of grounded theory (Martin \& Turner, 1986; Strauss \& Corbin, 1998) that adopts inductive reasoning by using existing theory on CS research (Freeman, 1984; Hart, 1997; Elkington, 2004; Porter \& Kramer, 2011; Visser, 2015) combined with practical SDG approaches from the field (Agarwal et al., 2017; GRI, UNGC \& WBCSD, 2015; Adams, 2017; WBCSD, 2018; Van Tulder, 2018) to develop an integrative framework for implementing the SDGs in practice.

In order to test and refine the preliminary model, we examine sustainability leaders' practices from the GlobeScan-SustainAbility Survey 2019. As part of the 2019 GlobeScan-SustainAbility Leaders Survey, over 800 experts representing business, government, NGOs and academia across 78 countries were asked to evaluate the progress that institutions have made since the 1992 Earth Summit (GlobeScanSustainAbility, 2019). By asking the question 'What specific companies do you think are leaders in integrating sustainability into their business strategy?', the 2019 Leaders Survey shows that Unilever, Patagonia and IKEA hold the top three positions in the top ten. Interface, Natura, Danone, Nestlé, Marks \& Spencer, Tesla and BASF follow with a great experience in CS (GlobeScan-SustainAbility, 2019).

The framework highlights four levels of SDG orientation that span seven steps of the SDG implementation process leading to sustainable transformation. 


\section{Findings}

In the first 'inform' stage, it is important for a company to get familiarized with the SDGs. Business leaders need to understand the opportunities this Agenda 2030 represent to their company (GRI, UNGC \& WBCSD, 2015). Firms need to understand the business case for CS and the SDGs by considering industry dynamics and the organization's external environment (Adams, 2017). Companies such as Unilever continue to be seen as the global leaders on sustainability who successfully understand the business case of the SDGs (GlobeScan \& SustainAbility, 2019). The former CEO of Unilever, Paul Polman, was appointed as Global SDG Advocate. During his 10 years leading the company, he focused on raising SDG awareness inside and outside the company and building an environmentally and socially responsible business (Unilever, 2017).

In the following 'activate' stage, stakeholder management is key. Listening and interacting with key stakeholders help to identify important sustainability issues and concerns (Freeman, 1984; GRI, UNGC \& WBCSD, 2015). Many companies execute a stakeholder assessment from an internally focused approach, by defining material issues well-known to their business. Nevertheless, this internally focused approach is not enough to address global needs. Therefore, it is equally important to explore - together with the stakeholders - global business challenges and opportunities related to the SDGs. For this, we suggest companies to execute a stakeholder assessment from an internally and externally focused approach.

In their Creating Shared Value (CSV) approach, Nestlé believes that the company can only be successful in the long term by creating value both for the shareholders and for society. The company identified material issues and designed a materiality matrix indicating the impact (direct or indirect) on achieving the SDGs. This way, Nestlé attaches a great importance to view these issues as interconnected and takes the first steps by looking at what is needed from a global perspective, linking to the 'outside-in' approach (Nestlé, 2019). By looking at what is needed from a global perspective, linking to 'outside-in' approaches such as the Science Based Targets initiative or the Future-Fit Benchmarks, and defining material issues accordingly, businesses will be able to bridge the gap between current business challenges and needed global performance (GRI, UNGC \& WBCSD, 2015).

In the same stage, it's important to take the values and guiding principles of Agenda 2030 into consideration. In the UN resolution on the 2030 Agenda (UN, 2015), the SDGs were specifically positioned as a universal, indivisible and interlinked set of goals. In this context, we argue that integrating the values of Agenda 2030 can help to challenge the traditional sustainability integration models: (1) universality - stressing that the goals apply to all countries, (2) integration and indivisibility - meaning that the SDGs need to be considered in their entirety and that the achievement of any one goal is linked to the achievement of the others, (3) aspiration and partnership - meaning there is a need to move past business as usual and seek transformational solutions and multistakeholder partnerships, (4) inclusiveness and leaving no one behind - calling for the participation of all segments of the society and stressing that success depends on the inclusion of the poorest and most vulnerable (UN, 2015). 
In the third 'innovate' stage, companies must set specific and measurable sustainability goals. By integrating sustainability goals, firms have the potential to transform the company's core business (GRI, UNGC \& WBCSD, 2015). With 'Plan A', Marks \& Spencer made 100 commitments to tackle five big issues - climate change, waste, resources, fair partnerships and health, which supports 15 of the SDGs. Through setting time-bound sustainability goals towards 2025, Marks \& Spencer continually wants to reflect on what they have learnt, foster shared priorities and drive performance across the organization (Marks \& Spencer, 2019).

Active leadership and governance by the senior management is key to the success of any type of organizational change. The support and ownership of several people within the company is the key to embedding sustainability in culture and operations. It is therefore important to develop integrated thinking and understand barriers and identify impact accelerators across the value chain. This will eventually open doors that can lead to sustainable innovation (GRI, UNGC \& WBCSD, 2015; Adams, 2017; WBCSD, 2018). As innovator, Tesla pushes the boundaries of their own business by continuously trying to optimize and open their imaginations to radically new possibilities. To reach true sustainable innovation, companies should ask themselves: How is the customer's culture evolving and how can demands be met by different and sustainable kinds of products and services (McDonough \& Braungart, 2002; Visser, 2014)?

The fourth 'transformation' stage emphasizes on the importance of reporting and communicating, by engaging with key stakeholders across the value chain. Most of the world's biggest companies now integrate financial and non-financial data in their annual financial reports, suggesting they believe sustainability information is relevant for investors (KPMG, 2017). Some companies want to understand and evidence their social and environmental impact activity and start experimenting with value measurement, such as $\mathrm{PwC}$ with Total Impact Measurement and Management, BASF with Value to Society, Impact Institute with True Price, Deloitte with Fair Value, EY with Long Term Value, and KPMG with True Value. A new initiative, which is called the Value Balancing Alliance, has the ambition to change the way how company performance is measured and valued. The objective is to create a global impact measurement standard for disclosing positive and negative value of corporate activity (Value Balancing Alliance, 2019).

With new initiatives to measure value, companies show leadership from a systemic, disruptive, inclusive, sustainable and ethical approach to provide meaningful answers to the challenges of society. By creating credible and compelling scenarios of the future, businesses have an important role to cause a positive movement. And by persevering meaningful innovations, companies are able to re-shape playing fields and review government policies that incentivize sustainable transformation (Visser, 2017). 


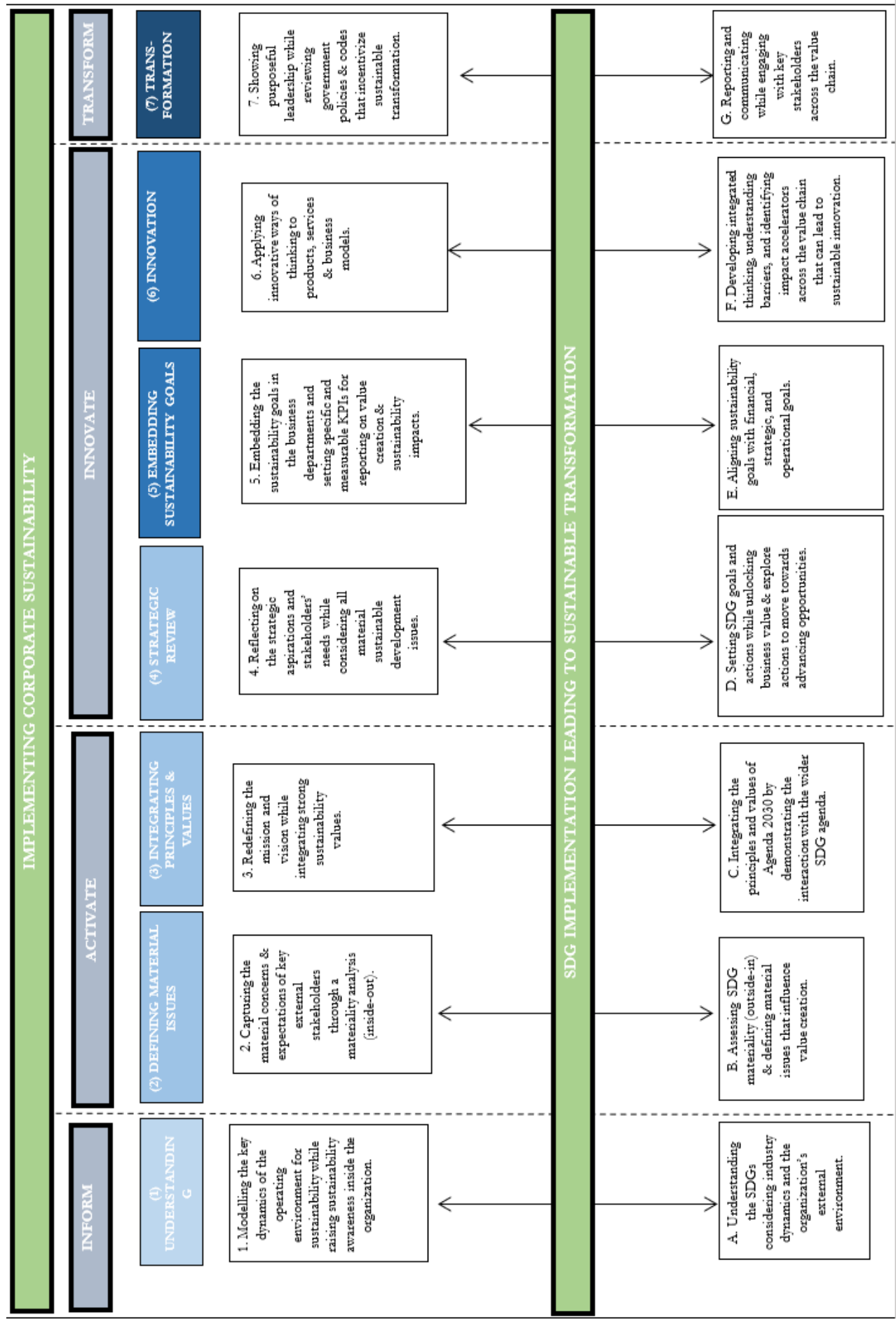

Figure 1: Proposed integrative framework for designing and implementing the SDGs leading to sustainable transformation 


\section{Discussion}

Our study addresses two main questions: First, we compare existing SDG frameworks as a means to capture the dynamics associated with adopting an SDG orientation. Second, on the basis of existing theory on CS and CSR research, the 7 steps of the IVM model (Visser, 2015) and the integrative CSR framework by Moan, Swaen and Lindgreen (2008), we identify four SDG orientation levels in the process of SDG implementation leading to sustainable transformation.

The findings give some insights into how effective the SDGs are in advancing sustainable transformation. First, the integrative framework in Figure 1 provides an initial roadmap for companies seeking to implement the SDGs leading to sustainable transformation. Next, the framework can be used to provide companies with a lens through which to translate global needs and ambitions into business strategies. When organizations embrace the SDGs, they are able to strengthen the engagement of customers and employees (GRI, UNGC \& WBCSD, 2015; WBCSD, 2018).

However, achieving the SDGs is beyond the reach of any single firm. We will only reach the transformative ambitions of the SDGs through collaboration, with companies plotting together a new course of the future (WBCSD, 2018). Only through purposeful leadership, persevering meaningful innovations, looking for new ways to measure value, and creating credible scenarios of the future, businesses can cause a positive movement which will re-shape playing fields and review government policies that incentivize sustainable transformation (Visser, 2017). The SDGs can help companies in this journey. The terms 'sustainable innovation' and 'sustainable transformation' can be interpreted in various ways. When discussing these concepts, we tried to be more specific about what we mean by sustainable innovation and transformation. Nevertheless, a more structured approach to understanding sustainable innovation and transformation is needed. In building this understanding, further theoretical and extensive empirical research can draw on the understanding of contextual issues and critical success factors that surround organizations who implement the SDGs in their strategy and operations.

In this sense, our study has some limitations. To improve methodological accuracy, future research should obtain more data and conduct in-depth interviews to assist in the development of precise insights. Likewise, instead of relying on the information of a few 'sustainable leaders', further studies might help to identify detailed SDG programs and existing tensions to SDG implementation and sustainable transformation.

\section{References}

Adams, C.A. 2017. The Sustainable Development Goals, integrated thinking and the integrated report. Retrieved from https://integratedreporting.org/resource/sdgs-integrated-thinking-and-theintegrated-report.

Agarwal, N., Gneiting, U., \& Mhlanga, G. 2017. Raising the bar: rethinking the role of business in the Sustainable Development Goals. Retrieved from https://www cdn.oxfam.org/s3fs-public/dpraising-the-bar-business-sdgs130217-en_0.pdf.

Arevalo, J., Castello, I., de Colle, S., Lenssen, G., Neumann, K., Zollo, M., Arevalo, J., Castelló, I., de Colle, S., Lenssen, G., Neumann, K. and Zollo, M. 2011. Introduction to the special issue: integrating 
sustainability in business models. Journal of Management Development, Vol. 30 No. 10, pp. 941 954.

Ashrafi, M., Adams, M., Walker, T. R., \& Magnan, G. 2018. How corporate social responsibility can be integrated into corporate sustainability: a theoretical review of their relationships. International Journal of Sustainable Development \& World Ecology, 25(8), 672-682.

BASF. 2017. Value-to-Society: Quantification and monetary valuation of BASF's impacts on society. Version 1.0. July 2017.

Blowfield, M., Visser, W., \& Livesey, F. 2007. Sustainability Innovation: Mapping the Territory. Cambridge Programme for Sustainability Leadership Paper Series, No. 2, 2007.

Bosch-Badia, M., Montllor-Serrats, J., Tarrazon, M. 2013. Corporate Social Responsibility from Friedman to Porter and Kramer. Theoretical Economics Letters, 3, 11-15, Department of Business Economics, Autonomous University of Barcelona.

Bowen, H. R. 2013. Social Responsibilities of the Businessman. Book collections on Project MUSE, University of Iowa Press.

Brundtland Commission. 1987. Report of the World Commission on Environment and Development: Our Common Future. Transmitted to the General Assembly as an Annex to document A/42/427 Development and International Co-operation: Environment.

Carpenter, A., Lozano, R., Huisingh, D. 2015. A Review of 'Theories of the Firm' and their Contributions to Corporate Sustainability. Journal of Cleaner Production, Vol 106, pp 430-442.

Carroll, A. 1999. Corporate Social Responsibility: Evolution of a Definitional Construct. Business \& Society 38(3): 268-295.

Danone. 2017. Danone contribution to the UN Sustainable Development Goals. http://iar2017.danone.com/performance-in-2017/our-contribution-to-the-uns-sustainabledevelopment-goals. [accessed March 19, 2020].

Danone. 2018. Integrated Annual Report 2018. https://iar2018.danone.com/ [accessed March 19, 2020].

Dawson, P. 2003. Understanding Organizational Change: The Contemporary Experience of People at Work, SAGE, 208 pages.

Dyllick, T., \& Hockerts, K. 2002. Beyond the business case for corporate sustainability. Business Strategy and the Environment, 11, 130-141.

Elkington, J. 1997. Cannibals with Forks: The Triple Bottom Line of 21st Century Business. Capstone, Oxford.

Epstein, M., Rejc Buhovac, A. \& Kristi Yuthas, K. 2015. Managing Social, Environmental and Financial Performance Simultaneously. Long Range Planning, Volume 48, Issue 1, Pages 35-45.

Evans S. 2017. Sustainable Value Creation: From Concept Towards Implementation. Sustainable Manufacturing pp 203-220.

Freeman R.E. 1984. Strategic Management: A Stakeholder Approach. Boston: Pitman.

Gasparatos, A., El-Haram, M., Horner, M. 2008. A critical review of reductionist approaches for assessing the progress towards sustainability. Environmental Impact Assessment Review, Volume 28, Issues 4-5.

Giddings, B. 2002. Environment, economy and society: Fitting them together into sustainable development. In Sustainable Development 10(4):187-196.

Global Compact. 2016. The UN Global Compact-Accenture Strategy CEO Study 2016. Retrieved from https://www.unglobalcompact.org/library/4331.

GlobeScan-SustainAbility. 2019. The GlobeScan-SustainAbility Survey 2019, https://globescan.com/wpcontent/uploads/2019/07/GlobeScan-SustainAbility-Leaders-Survey-2019-Report.pdf [accessed February 19, 2020].

GRI, UNGC \& WBCSD. 2015. SDG Compass: the guide for business action on the SDGs. https://sdgcompass.org

Hart, S. \& Milstein, M. 2003. Creating Sustainable Value, Academy of Management Executive, Vol. 17, No. 2 .

Hart, S. 2007. Capitalism at the Crossroads: Aligning Business, Earth and Humanity, Wharton School Publishing.

IKEA. 2018. IKEA Sustainability Report https://preview.thenewsmarket.com/Previews/IKEA/DocumentAssets/535135.pdf [accessed March 24, 2020]. 
Interface. 2019. Corporate website: https://www.interface.com/US/en-US/about/mission [accessed March 27, 2020].

KMPG. 2017. The KPMG Survey of Corporate Responsibility Reporting 2017. Publication number: 134802 Publication date: October 2017.

Langer, M. \& Schön, A. 2003. Enhancing corporate sustainability. A framework based evaluation tool for sustainable development. Political Science.

Laufer, W. 2003. Social Accountability and Corporate Greenwashing. Journal of Business Ethics volume 43, pages 253-261.

Lockett, A., Moon, J., \& Visser, W. 2006. Corporate social responsibility in management research: Focus, nature, salience and sources of influence. Journal of Management Studies, 43(1): 115-136.

Lozano, R. 2011. Creativity and Organizational Learning as Means to Foster Sustainability. Sustainability: The Journal of Record, Vol. 12, No. 2 Case Reports.

Lozano, R. 2012. Towards better embedding sustainability into companies' systems: an analysis of voluntary corporate initiatives. Journal of Cleaner Production, 25(0), 14-26.

Maon, F., Swaen, V., \& Lindgreen, A. 2008. Designing and Implementing Corporate Social Responsibility: An Integrative Framework Grounded in Theory and Practice. Journal of Business Ethics 87:7189.

Marks \& Spencer. 2020. Plan A 2025. https://corporate.marksandspencer.com/sustainability/report2018 [accessed March 27, 2020].

Marks \& Spencer. 2020. Corporate website: https://corporate.marksandspencer.com/sustainability [accessed March 27, 2020].

Martin, P. \& Turner, B. 1986. Grounded Theory and Organizational Research. The Journal of Applied Behavioral Science, vol. 22, no. 2, 141.

McDonough, W. \& Braungart, M. 2002. Cradle to Cradle: Remaking the Way We Make Things. Farrar, Straus and Giroux.

Meadows, D., Randers, J., Behrens III, W. 1972. The Limits to Growth; A Report for the Club of Rome's Project on the Predicament of Mankind. New York: Universe Books.

Montiel, I. \& Delgado-Ceballos, J. 2014. Defining and Measuring Corporate Sustainability: Are We There Yet? Organization \& Environment 27(2):113-139.

Morandín-Ahuerma, I., Contreras-Hernández, A., Ariel Ayala-Ortiz, D. \& Pérez-Maqueo, O. 2019. SocioEcosystemic Sustainability. In Sustainability 11(12):3354.

Moratis, L. 2017. Patagonia case study: long-term values over short-term gains, https://blog.antwerpmanagementschool.be/en/case-study-patagonia-long-term-values-overshort-term-gains [accessed March 25, 2020].

Mori, R. J., Fien, J. \& Horne, R. 2019. Implementing the UN SDGs in Universities: Challenges, Opportunities, and Lessons Learned. Sustainability: The Journal of Record, Vol. 12, No. 2.

Nestle. 2020. Corporate website: https://www.nestle.com/csv [accessed March 27, 2020].

Patagonia.

2018.

Annual

Benefit

Corporation

Report

2018. https://www.patagonia.com/static/on/demandware.static/-/Library-Sites-

PatagoniaShared/default/dw824fac0f/PDF-US/2017-BCORP-pages_022218.pdf [accessed March 25, 2020].

Patagonia. 2020. Corporate website: https://eu.patagonia.com/gb/en/sustainability.html [accessed March $25,2020]$.

Porter, M. \& Kramer, M. 2006. Strategy \& Society, the Link between Competitive Advantage and Corporate Social Responsibility. Harvard Business Review, Vol. 84, No. 12, pp. 78-92.

Porter, M. \& Kramer, M. 2018. Creating Shared Value: How to Reinvent Capitalism-And Unleash a Wave of Innovation and Growth, Managing Sustainable Business pp 323-346.

PwC (2018). From promise to reality: Does business really care about the SDGs?. Retrieved from https://www.pwc.com/gx/en/sustainability/SDG/sdg-reporting-2018.pdf

Rauter, R., Jonker, J. \& Baumgartner, R. 2017. Going one's own way: drivers in developing business models for sustainability. Journal of Cleaner Production. Volume 140, Part 1, 1 January 2017, Pages 144154.

Raworth, K. 2014. Will these Sustainable Development Goals get us into the Doughnut? Retrieved from https://www.kateraworth.com/2014/08/11/will-these-sustainable-development-goals-get-usinto-the-doughnut. 
Rosati, F., \& Faria, L. G. 2019. Addressing the SDGs in sustainability reports: The relationship with institutional factors. Journal of Cleaner Production, 215, 1312-1326.

Saunders, M., Lewis, P., Thornhill, A. \& Bristow, A. 2019. Research Methods for Business Students: Chapter 4: Understanding research philosophy and approaches to theory development. In book: Research Methods for Business Students, Edition: 8, Chapter: 4, Publisher: Pearson Education, pp.128-171.

Senge, P., Smith, B., Kruschwitz, N., Laur, J. \& Schley, S. \& Brealy, N. 2008. The Necessary Revolution: How Individuals and Organizations Are Working Together to Create a Sustainable World, 432 pages.

Schönherr, N., Findler, F. \& Martinuzzi, A. 2017. Exploring the interface of CSR and the Sustainable Development Goals. TRANSNATIONAL CORPORATIONS - Volume 24, Number 3.

Seth, A., \& Thomas, H. 1994. Theories of the firm: Implications for research. Journal of Management Studies, 31(2), 165-191.

Stake, R. E. 2005. Qualitative Case Studies. In N. K. Denzin \& Y. S. Lincoln (Eds.), The Sage handbook of qualitative research (p. 443-466). Sage Publications Ltd.

Strauss, A., \& Corbin, J. 1998. Basics of Qualitative Research: Techniques and Procedures for Developing Grounded Theory. Thousand Oaks, CA: Sage Publications, Inc.

Surie, G., Ashley. A. 2008. Integrating Pragmatism and Ethics in Entrepreneurial Leadership for Sustainable Value Creation. Journal of Business Ethics, Volume 81, Issue 1, pp 235-246

Tesla. 2018. Tesla Impact Report 2018, https://www.tesla.com/ns_videos/tesla-impact-report-2019.pdf [accessed March 26, 2020].

Thomson, S. B. 2010. Grounded Theory - Sample Size. Journal of Administration and Governance, 5(1), 4552.

Thomson, I. 2015. 'But does sustainability need capitalism or an integrated report' a commentary on 'The International Integrated Reporting Council: A story of failure' by Flower, J. Critical Perspectives on Accounting, Volume 27, Pages 18-22.

Thurmond, V. 2004. The point of triangulation. Journal of nursing scholarship. Volume 33, Issue 3, Pages 253-258.

UNDP. 2015. The Millennium Development Goals Report 2015.

UNGC. 2010. United Nations Global Compact Leaders Summit 2010 - Summary Report.

Unilever. 2017. Sustainable Living Report 2017, https://www.unilever.com/Images/sustainable-livingreport-2017_tcm244-537865_en.pdf [accessed March 23, 2020].

Unilever. 2018. Sustainable Living Plan Performance Summary 2018, https://www.unilever.com/Images/uslp-performance-summary-2018_tcm244-536032_en.pdf. [accessed March 23, 2020].

Unilever. 2019. Unilever Sustainable Living Plan 2019, https://www.unilever.com/sustainable-living. [accessed March 23, 2020].

United Nations. 2000. The Millennium Development Goals. Retrieved from http://www.un.org/millenniumgoals.

United Nations. 2015. Transforming our world: The 2030 agenda for sustainable development. Resolution adopted by the General Assembly.

United Nations. 2017. The Sustainable Development Goals report 2017. Retrieved from https://unstats.un.org/sdgs/files/report/2017/thesustainabledevelopmentgoalsreport20 7.pdf

Value Balancing Alliance. 2019. Retrieved from https://www.value-balancing.com.

Van de Ven, A. \& Poole, M. S. 1995. Explaining Development and Change in Organizations. The Academy of Management Review, Vol. 20, No. 3, pp. 510-540.

Van Tulder, R. \& Van Zanten J. A. 2018. Multinational enterprises and the Sustainable Development Goals: An institutional approach to corporate engagement. Journal of International Business Policy volume 1, pages 208-233.

Van Tulder, R. \& Lucht, L. 2019. Reversing Materiality: From a Reactive Matrix to a Proactive SDG Agenda: Select Proceedings of IC3E 2018. Recent Trends in Communication, Computing, and Electronics, pp.271-289.

Vilanova, M., Lozano. J. \& Arenas, D. 2009. Exploring the Nature of the Relationship between CSR and Competitiveness. Journal of Business Ethics, Vol. 87, No. 1, pp. 57-69.

Visser, W. 2014. Eco-innovation: going beyond creating technology for technology's sake. The Guardian, 4 December 2014. 
Visser, W. \& Kymal, C. 2015. Integrated Value Creation (IVC): Beyond Corporate Social Responsibility (CSR) and Creating Shared Value (CSV). Journal of International Business Ethics, Vol.8, No.1.

Visser, W. 2017. Sustainable Transformation: The Journey of a Thousand Miles, https://www.researchgate.net/publication/322988422_Sustainable_Transformation_The_Journey _of_a_Thousand_Miles. [accessed March 23, 2020].

Wartick, S. \& Cochran, Ph. 1985. The Evolution of the Corporate Social Performance Model. The Academy of Management Review, Vol. 10, No. 4, pp. 758-769.

WBCSD. 2016. Delivering on the SDGs: The inclusive business approach. Retrieved from www.wbcsd.org.

WBCSD. 2018. SDG Sector Roadmaps. Retrieved from https://docs.wbcsd.org/2018/04/SDG_roadmap\%20Guidelines.pdf

Witte, C., \& Dilyard, J. 2017. Guest editors' introduction to the special issue: The contribution of multinational enterprises to the Sustainable Development Goals. Transnational Corporations, 24(3), 1-8.

Yancey, P. \& Turner, B. 1986. Grounded Theory and Organizational Research. The Journal of Applied Behavioral Science, vol. 22, no. 2 (1986), 141.

Young, D. \& Woods, W. 2019. Innovation Is the Only Way to Win the SDG Race. Retrieved from https://www.bcg.com/publications/2019/innovation-win-sdg-race.aspx. 